\title{
ANALISIS PENGARUH PENERIMAAN KAS DAN PENGELUARAN KAS TERHADAP PROFIT PT. RESTU KHAIRI PRATAMA (STUDI KASUS TAHUN 2016-2018)
}

\author{
Fauzan Haqiqi ${ }^{1}$, Raja Nanda Alkausar ${ }^{2}$ Ferawati $^{3}$, Azmia Laily \\ Program Studi Akuntansi, Fakultas Ilmu Sosial dan Humaniora, Universitas Karimun, Provinsi \\ Kepulauan Riau, Indonesia \\ Email : fauzanhaqiqi.1986@gmail.com ${ }^{1}$, nandahong.nh@gmail.com ${ }^{2}$, \\ fera.universitaskarimun@gmail.com ${ }^{3}$
}

\begin{abstract}
Abstrak
Penelitian ini bertujuan untuk mengetahui pengaruh antara penerimaan kas dan pengeluaran kas terhadap profit secara parsial dan simultan PT. Restu Khairi Pratama. Jenis penelitian bersifat kuantitatif dengan menggunakan data sekunder yang diperoleh dari laporan internal perusahaan. Teknik sampling yang digunakan adalah nonprobability sampling yaitu teknik sampling dengan menggunakan pertimbangan khusus atau (purposive sampling) dengan menggunakan laporan yang diambil dari tahun 20162018. Teknik analisis data yang digunakan dalam penelitian ini menggunakan metode verifikasi dengan pendekatan kuantitatif. Hasil uji t menunjukkan bahwa penerimaan kas tidak berpengaruh terhadap profit dibuktikan nilai t hitung sebesar 1.489 lebih kecil dari t table sebesar 1.692 dan signifikan sebesar $0.00<$ dari tingkat signifikansi yang disyaratkan yaitu 0.05 . hasil uji t menunjukkan bahwa tingkat pengeluaran kas tidak berpengaruh terhadap profit. Hal ini dibuktikan dengan nilai t hitung sebesar -809 lebih kecil dari t tabel sebesar 1.692 dan signifikansi yang disyaratkan yaitu 0.05. Secara simultan penerimaa kas dan pengeluaran kas terhadap profit tidak berpengaruh dibuktikan dengan nilai $\mathrm{F}$ hitung sebesar 1.127 lebih kecil dari pada $\mathrm{F}$ tabel sebesar 3.285 dan signifikansi sebesar $0.00<$ dari tingkat signifikansi yang disyaratkan yaitu 0.05 .
\end{abstract}

Kata Kunci : Penerimaan Kas, Pengeluaran Kas, dan Profit

\section{PENDAhUluan}

Situasi Lingkungan bisnis yang semakin pesat seperti saat ini, setiap organisasi bisnis dituntut untuk selalu meningkatkan kemampuan dan daya saing yang memadai.Hal yang paling penting yang harus dilakukan perusahaan agar mampu meningkatkan kegiatan usahanya adalah bahwa setiap perusahaan harus dapat melaksanakan kegiatan rutin usahanya.Untuk dapat melaksanakan kegiatan rutin usahanya manajemen perusahaan memerlukan dukungan informasi dan komunikasi yang baik agar perusahaan dapat mencapai tujuan secara efektif dan efesien Akuntansi sangat erat hubungannya dengan organisasi atau perusahaan untuk mencapai tujuan yang diharapkan.Dalam akuntansi manajemen perusahaan harus bisa merancang dan melaksanakan akuntansi yang baik untuk menangani kegiatan pokok perusahaan.kegiatan akuntansi yang digunakan untuk menangani kegiatan pokokperusahaan jasa atau manufaktur meliputi kegiatan penjualan, pembelian, penggajian dan pengupahan, penerimaan dan pengeluaran kas, mutasi aktiva tetap.

PT. Restu Khairi Pratama merupakan salah satu satu Agent Pelayaran yang ada di Tanjung Balai Karimun yang bergerak dibidang jasa Pelayaran.PT. Restu Khairi 
Pratama juga membuka Trayek-trayek dengan tujuan pelayaran hingga kedaerah-daerah pedalaman dan terpencil agar pemerataan pembangunan diindonesia dapat terwujud.Seiring dengan perkembangan zaman semakin banyak permintaan masyarakat terhadap jasa angkutan laut.Maka dari itu PT. Restu Khairi Pratama membuka perusahaan jasa pelayaran di wilayah Tanjung Balai Karimun. Namun pada tahun 20162018 PT. Restu Khairi Pratama mengalami penurunan financial . Hal ini menunjukkan selisih Minus antara penerimaan kas dan pengeluaran kas cukup prihatin. Selisih Minus tersebut disebabkan oleh beberapa faktor, salah satunya adalah pengeluaran kas yang cukup besar dibandingkan dengan penerimaan kas yang diterima.

Tabel 1.1

Tingkat penerimaan kas PT. Restu Khairi Pratama 2016-2018

\begin{tabular}{|c|c|c|c|}
\hline \multirow{2}{*}{ BULAN } & \multicolumn{3}{|c|}{ TAHUN } \\
\hline & 2016 & 2017 & 2018 \\
\hline JANUARI & Rp. 60.750 .000 & Rp. 58.300 .000 & Rp. 61.250 .000 \\
\hline FEBRUARI & Rp. 57.800.000 & Rp. 58.300.000 & Rp. 60.750 .000 \\
\hline MARET & Rp. 59.450 .000 & Rp. 59.750 .000 & Rp. 61.300 .000 \\
\hline APRIL & Rp. 59.800.000 & Rp. 60.050 .000 & Rp. 62.500 .000 \\
\hline MEI & Rp. 61.300 .000 & Rp. 58.700 .000 & Rp. 62.050 .000 \\
\hline JUNI & Rp. 58.150.000 & Rp. 58.650 .000 & Rp. 61.900 .000 \\
\hline JULI & Rp. 60.900 .000 & Rp. 60.350 .000 & Rp. 61.850 .000 \\
\hline AGUSTUS & Rp. 57.750.000 & Rp. 60.050 .000 & Rp. 62.000 .000 \\
\hline SEPTEMBER & Rp. 62.100 .000 & Rp. 61.300 .000 & Rp. 61.950.000 \\
\hline OKTOBER & Rp. 62.050 .000 & Rp. 60.950 .000 & Rp. 59.900.000 \\
\hline NOVEMBER & Rp. 59.800.000 & Rp. 61.050 .000 & Rp. 59.750 .000 \\
\hline DESEMBER & Rp. 58.950.000 & Rp. 60.900 .000 & Rp. 60.050 .000 \\
\hline
\end{tabular}

Tabel 1.2

Tingkat pengeluaran kas PT. Restu Khairi Pratama Tahun 2016-2018

\begin{tabular}{|c|c|c|c|}
\hline \multirow{2}{*}{ BULAN } & \multicolumn{3}{|c|}{ TAHUN } \\
\hline & 2016 & 2017 & 2018 \\
\hline JANUARI & Rp. 31.117 .500 & Rp. 29.900 .800 & Rp. 33.050 .000 \\
\hline FEBRUARI & Rp. 31.555 .900 & Rp. 31.332.000 & Rp. 32.924 .400 \\
\hline MARET & Rp. 30.922 .300 & Rp. 31.727.500 & Rp. 32.715.100 \\
\hline APRIL & Rp. 31.227 .000 & Rp. 30.952 .000 & Rp. 33.215.700 \\
\hline MEI & Rp. 31.472 .100 & Rp. 30.981 .700 & Rp. 33.112.200 \\
\hline JUNI & Rp. 31.528 .000 & Rp. 31.375.200 & Rp. 32.951 .600 \\
\hline JULI & Rp. 32.127 .800 & Rp. 31.811 .700 & Rp. 33.872 .200 \\
\hline AGUSTUS & Rp. 32.175 .000 & Rp. 32.428 .800 & Rp. 33.727 .700 \\
\hline SEPTEMBER & Rp. 32.314 .400 & Rp. 32.124.100 & Rp. 33.422 .000 \\
\hline OKTOBER & Rp. 31.050 .400 & Rp. 32.982 .700 & Rp. 32.832.100 \\
\hline NOVEMBER & Rp. 31.743 .700 & Rp. 32.617.100 & Rp. 33.472 .800 \\
\hline DESEMBER & Rp. 30.318 .800 & Rp. 32.697 .300 & Rp. 32.925 .500 \\
\hline
\end{tabular}




\section{Tingkat Profit PT. Restu Khairi Pratama Tahun 2016-2018}

\begin{tabular}{|c|c|c|c|}
\hline \multirow{2}{*}{ BULAN } & \multicolumn{3}{|c|}{ TAHUN } \\
\cline { 2 - 4 } & $\mathbf{2 0 1 6}$ & $\mathbf{2 0 1 7}$ & $\mathbf{2 0 1 8}$ \\
\hline JANUARI & Rp. 29.632.500 & Rp. 28.399.000 & Rp. 28.200.000 \\
\hline FEBRUARI & Rp. 26.244.100 & Rp. 26.968.000 & Rp. 27.825.600 \\
\hline MARET & Rp. 28.527.700 & Rp. 28.022.500 & Rp. 28.584.900 \\
\hline APRIL & Rp. 28.573.000 & Rp. 29.098.000 & Rp. 29.284.300 \\
\hline MEI & Rp. 29.827.900 & Rp. 27.718.300 & Rp. 28.937.800 \\
\hline JUNI & Rp. 26.622.000 & Rp. 27.274.800 & Rp. 28.948.400 \\
\hline JULI & Rp. 28.772.200 & Rp. 28.538.300 & Rp. 27.977.800 \\
\hline AGUSTUS & Rp. 25.575.000 & Rp. 27.621.200 & Rp. 28.272.300 \\
\hline SEPTEMBER & Rp. 29.785.600 & Rp. 29.175.900 & Rp. 28.528.000 \\
\hline OKTOBER & Rp. 30.999.600 & Rp. 27.967.300 & Rp. 27.067.900 \\
\hline NOVEMBER & Rp. 28.056.300 & Rp. 28.432.900 & Rp. 26.277.200 \\
\hline DESEMBER & Rp. 28.631.200 & Rp. 28.202.700 & Rp. 27.124.500 \\
\hline
\end{tabular}

\section{Identifikasi Masalah}

Berdasarkan uraian latar belakang diatas pokok permasalahan yang akan dibahas dalam penelitian ini adalah

1. Terjadinya keselisihan penerimaan kas dan pengeluaran kas yang mengakibatkan pofit atau keuntungan berdampak buruk dikarenakan tidak sesuai dengan tujuan perusahaan.

2. Terjadi naik turunya penerimaan kas dan pengeluaran kas yang mengakibatkan pofit atau keuntungan menjadi tidak stabil yang diinginkan perusahaan

\section{A. Penerimaan Kas}

Penerimaan Kas ( Cash Receipt) adalah transaksi keuangan yang menyebabkan Asset perusahaan berupa kas atau setara kas bertambah. Transaksi penerimaan kas dicatat ke sistem computer pada formulir elektronik penerimaan kas sesuai dengan method yang ditetapkan. Setiap penerimaan kas selain nilai nominal juga harus menunjukkan tanggal transaksi, tanggal efektif, dokumen referensi, buyer, sumber penerimaan kas, transaksi yang terkait, keterangan ringkas,dll. Penambahan kas yang dicatat pada jurnal memorial.

Menurut (Haryono Yusup,2001:406) "penerimaan kas pada sebuah perusahaan dapat dikelompokkan menjadi tiga yaitu penerimaan kas dari penjualan tunai, penerimaan dari debitur dan penerimaan kas dari sumber lain-lain". Sedangkan Menurut Mulyadi (2001:455) "penerimaan kas perusahaan berasal dari dua sumber utama yaitu penerimaan kas dari penjualan tunai dan penerimaan kas dari piutang

Penerimaan kas dapat berasal dari berbagai macam sumber diantaranya seperti pelunasan piutang, penjualan tunai tetapi ada juga sumber penerimaan yang jarang terjadi seperti penjualan aktiva tetap. Penerimaan kas bisa berbagi macam cara seperti pos, pembayaran langsung kekasir atau pelunasan kebank. Prosedur penerimaan uang melibatkan beberapa bagian dalam perusahaan agar transaksi penerimaan uang tidak terpusat pada suatu bagian saja.Hal ini perlu agar dapat memenuhi prinsip-prinsip 
internal control. Baridwan (1997:87) mengemukakan bahwa untuk menghindari adanya tindakan manipulasi

Akuntansi Penerimaan Kas adalah suatu catatan yang dibuat untuk melaksanakan kegiatan penerimaan uang dari penjualan tunai atau dari piutang yang siap dan bebas digunakan untuk kegiatan umum perusahaan. Sistem Akuntansi Penerimaan Kas adalah proses aliran kas yang terjadi di perusahaan. Aliran kas terdiri dari aliras kas masuk dan aliran kas keluar.

\section{B. Cash Payment}

Pengeluaran Kas (Cash Payment) adalah transaksi pengeluaran uang secara tunai yang meneyebabkan berkurangnya aset perusahaan berupa kas, bank atau setara kas lainnya. Transaksi pengeluaran kas meliputi pembayaran utang, pembelian barang dagangan, pembelian bahan baku, pembelian bahan pembantu, pembelian perlengkapan kantor, pembentukan dana kas kecil.

Menurut mulyadi (2001) dalam bukunya, sistem akuntansi adalah organisasi formulir, catatan dan laporan yang dikoordinasikan sedemikian rupa untuk menyediakan informasi akuntansi keuangan yang dibutuhkan oleh manajemen untuk menentukan kebijakan dalam pengelolaan kinerja perusahaan.

Jadi dapat disimpulkan bahwa pengeluaran kas pada umumnya di definiskan sebagai organisasi formulir, catatan, dan laporan yang dibuat untuk melaksanakan kegiatan pengeluaran baik dengan cek maupun uang tunai untuk mempermudah setiap mempermudah setiap pembiyaan pengelolaan perusahaan.

Secara garis besar pengeluaran kas perusahaan dilakukan melalui dua sistem, yaitu sistem pengeluaran kas dengan cek dan sistem pengeluaran kas dengan uang tunai melalui dana kas kecil. Pengeluaran kas yang dilakukan dengan tunai biasanya karena jumlahnya relatif kecil.

Ada juga pengertian lain, pengeluaran kas merupakan sistem yang digunakan untuk mencatat seluruh transaksi pengeluaran kas, yang meliputi serangkaian proses kegiatan menerima, menyimpan, menyetor, membayar, menyerahkan dan mempertanggung jawabkan pengeluaran uang yang berada dalam pengelolaan suatu perusahaan. Sistem akuntansi pengeluaran kas terdiri dari dua sistem pokok, yaitu sistem akuntansi pengeluaran kas dengan cek dan sistem pengeluaran kas dengan uang tunai melalui sistem dana kas kecil

\section{Profit}

Profit adalah keuntungan Finansial yang didapatkan perusahaan dari aktivitas bisnis yang dilakukan. Keuntungan didapatkan dari mengurangi biaya dengan pendapatan atau Omzet perusahaan.Pendapatan perusahaan haruslah lebih tinggi dari biaya yang digunakan, agar selisih pengurangan yang didapat memiliki nilai Positif.Ada tiga jenis pengelompokan profit didalam ilmu ekonomi, yaitu:

\section{a. Gross Profit (laba Kotor)}

Laba kotor adalah salah satu jenis profit yang didapat dengan mengurangi pendapatan selama satu periode dengan harga pokok penjualan. Perhitungan dengan cara ini hanya memfokuskan biaya variable sebagai dasar perhitungan terhadap laba yang didapat. Biaya tetap yang harus dibayarkan terlepas dari tinggi rendahnya volume produksi perusahaan. 


\section{b. Operating Profit (Laba Operasional)}

Laba Operasional adalah laba yang didapat dari pengurangan laba kotor dengan biaya operasi yang dikeluarkan oleh perusahaan.Biaya operasi biasanya adalah biaya administrasi dan biaya lainnya yang dibutuhkan perusahaan dalam menjalankan operasinya Sehari-hari, dalam menghitung laba operasional tidak diperbolehkan mengikutsertakan pendapatan diluar aktivitas bisnis seperti pendapatan dari investasi dan juga pajak dibebankan.Perhitungan Operating Profit sebuah perusahaan dapat digunakan untuk mengukur seberapa besar potensi keuntungan perusahaan tanpa memperhatikan faktor eksternal, seperti pajak ataupun hutang.

\section{c. Net Profit (laba Bersih)}

Laba bersih diketahui dari cara mengurangi laba operasional dengan pajak ataupun bunga yang dibebankan kepada perusahaan.

Ketiga jenis profit atau keuntungan diatas nantinya sangat berguna untuk melihat apakah suatu perusahaan mengalami kerugian atau tidak. Untuk itu ada juga istilah yang disebut dengan Profit Margin.

Profit Margin adalah salah satu cara yang umum digunakan untuk mengukur aktivitas bisnis atau barang apa yang paling menghasilkan uang. Setiap industry memiliki Profit Margin yang berbeda-beda, jadi tidak dapat membandingkan antara perusahaan satu dan perusahaan lainnya.

Margin sendiri adalah cara menilai kesehatan keuangan perusahaan berdasarkan dari uang yang tersisa dari pengurangan omzet yang didapatkan dengan harga pokok penjualan.

Menurut Fauzan Haqiqi, Darmawan, \& Kasirul Fadli. (2020), Salah satu cara perusahaan untuk mendapatkan keuntungan yaitu dengan memberikan kredit pada nasabahnya. Kredit sangat penting bagi profitabilitas karena dengan adanya peningkatan atau perkembangan kredit yang disalurkan setiap tahunnya, maka akan meningkatkan pula profitabilitasnya. Tujuan Penelitian untuk mengetahui pengaruh secara Parsial antara Likuiditas (X1) terhadap Tingkat Profitabilitas (Y), Pemberian Kredit (X2) terhadap Tingkat Profitabilitas (Y) dan untuk mengetahui pengaruh secara Simultan antara Likuiditas (X1) dan Pemberian Kredit (X2) terhadap Profitabilitas (Y) pada Bank BPR Mega Mas Lestari Tahun 2016-2018. Hasil penelitian; Uji t (Parsial) membuktikan Hipotesis Pertama (Ha1) diterima, artinya terdapat pengaruh variabel Likuiditas (X1) terhadap Profitabilitas (Y), dimana nilai thitung $(7,553)>\mathrm{t}$ Tabel $(2,042)$, dan berdasarkan nilai signifikan, Nilai sig $0,000<0,05$. Uji t (Parsial) membuktikan Hipotesis Kedua (Ha2) ditolak, artinya tidak terdapat pengaruh variabel Pemberian Kredit (X2) terhadap Profitabilitas (Y), dimana nilai thitung $(0,955)<\mathrm{t}$ Tabel $(2,042)$, dan berdasarkan nilai signifikan, Nilai sig 0,347 >0,05. Uji f (simultan) membuktikan Hipotesis ketiga (Ha3) diterima artinya terdapat Pengaruh variabel Likuiditas (X1) dan variabel Pemberian Kredit (X2) terhadap Profitabilitas (Y), berdasarkan output SPSS d idapati nilai $\mathrm{F}$ hitung sebesar 162.883. Karena nilai Fhitung $(162.883)>$ F Tabel $(3,305)$ maka Ha3 Diterima dan Ho3 Ditolak dan berdasarkan nilai sig 0,00<0,05. Uji Detreminan membuktikan nilai R Square 0,910 dengan variable independen X1 dan X2. Artinya bahwa kontribusi nilai X1 dan X2 dalam menjelaskan variabel Y ialah sebesar 91,6\% dan dan sisanya 8,4\% dijelaskan oleh variable lain diluar variabel yang diuji. 


\section{Hipotesis}

Ha1: Terdapat pengaruh yang signifikan antara variabel penerimaan kas terhadap profit pada PT. Restu Khairi Pratama

Ho1:Tidak terdapat pengaruh yang signifikan antara variabel penerimaan kas terhadap profit pada PT. Restu Khairi Pratama

Ha2 :Terdapat pengaruh yang signifikan antara variabel pengeluaran kas terhadap profit pada PT. Restu Khairi Pratama

Ho2: Tidak terdapat pengaruh yang signifikan antara variabel pengeluaran kas terhadap profit pada PT. Restu Khairi Pratama

Ha3: Terdapat pengaruh yang signifikan antara variabel penerimaan kas dan pengeluaran kas terhadap profit pada PT. Restu Khairi Pratama

Ho3: Tidak terdapat pengaruh yang signifikan antara variabel penerimaan kas dan pengeluaran kas terhadap profit pada PT. Restu Khairi Pratama

\section{METODE PENELITIAN}

\section{A. Jenis dan Sumber Data}

Jenis data penelitian ini merupakan penelitian Kuantitatif. Kuantitatif adalah pendekatan yang menekankan pada pengujian teori-teori atau hipotesis-hipotesis melalui pengukuran variabel-variabel penelitian dalam angka (quantitative) dan melakukan analisis data dengan Prosedur statis dan pemodelan sistematis.

Sumber data dalam penelitian ini menggunakan data sekunder. Data sekunder yaitu data yang diperoleh dalam bentuk yang sudah jadi, yang dikumpulkan dan diolah oleh pihak lain biasanya sudah dalam bentuk publikasi. Penelitian ini mengambil data atau informasi melalui akses internet ke website dan link lainnya yang memberikan tambahan informasi tentang masalah dalam penelitian.Sumber data dalam penelitian ini menggunakan data sekunder berupa laporan keuangan PT. Restu Khairi Pratama.

Tabel 2.1

Definisi Operasional dan Variabel Penelitian

\begin{tabular}{|l|l|c|}
\hline \multicolumn{1}{|c|}{ Variabel Penelitian } & \multicolumn{1}{|c|}{ Indikator } & Skala \\
\hline Variabel X1 (Penerimaan Kas) & $\begin{array}{l}\text { Cash , Surat berharga, } \\
\text { Pelunasan Piutang }\end{array}$ & Rasio \\
\hline Variabel X2 (Pengeluaran Kas) & $\begin{array}{l}\text { Biaya jasa, Biaya lain- } \\
\text { perlengkapan Biaya } \\
\text { lain }\end{array}$ & Rasio \\
\hline Variabel Y (Profil & $\begin{array}{l}\text { Pendapatan jasa, Beban } \\
\text { Operasional }\end{array}$ & Rasio \\
\hline
\end{tabular}




\section{B. Populasi dan Sampel}

Populasi dalam penelitian ini bergerak dibidang jasa keagenan pelayaran dimana populasi tersebut adalah laporan keuangan yang terdiri dari neraca dan laba rugi yang berjumlah 36 sampel.

Sampel adalah sebagian dari yang diteliti.Penentuan jumlah sampel dalam penelitian ini dilakukakn dengan taraf signifikan 5\% dari populasi. Salah satu metode yang digunakan untuk menentukan jumlah sampel adalah menggunakan rumus Slovin, dimana rumus tersebut menghitung jumlah sampel dari sebuah populasi.

Adapun rumus Slovin sebagai berikut

$$
\begin{aligned}
n=\frac{N}{1+N e^{2}} & \\
\mathrm{~N}=\text { Jumlah sampel } & \\
\mathrm{e}=\text { Jumlah Seluruh Populasi } &
\end{aligned}
$$

Dimana telah dibuat dalam metode tersebut ialah :

$$
\begin{aligned}
\mathrm{N} & =\frac{\mathrm{N}}{1+{\mathrm{N} \cdot \mathrm{e}^{2}}^{2}} \\
& =\frac{36}{1+36 \cdot(5 \%)^{2}} \\
& =\frac{36}{1+36 \cdot(0,05)^{2}} \\
& =\frac{36}{1+36 \cdot(0,0025)} \\
& =\frac{36}{1+0.09} \\
& =\frac{36}{1.09} \\
& =33
\end{aligned}
$$

\section{Metode Analisis Data}

1) Uji Normalitas

Uji normalitas data dilakukan untuk melihat apakah suatu data terdistribusi secara normal atau tidak.Tujuan uji normalitas adalah mengetahui apakah dalam model regresi variabel pengganggu atau residual memiliki distribusi normal. Cara untuk mendeteksi apakah residual berdistribusi normal atau tidak adalah dengan dilakukan Kolmogorov Sminov test yang terdapat pada program SPSS. Distribusi data dapat dikatakan normal apabila signifikansi $>0,05$, dalam penelitian ini juga menggunakan Grafik Normal Probability Plots, dasar pengembalian keputusan yang dilakukan adalah sebagai berikut:

a. Jika data menyebar disekitar garis diagonal dan mengikuti arah garis diagonal, maka regresi memenuhi asumsi normalitas 
b. Jika data menyebar jauh dari garis diagonal dan tidak mengikuti arah garis diagonal, maka regresi tidak memenuhi asumsi normalitas

2) Uji Multikolineritas

Multikolinieritas dikemukakan pertama kali oleh Ragner Frish yang mana menyatakan bahwa multikolinier adalah adanya lebih dari satu hubungan linier yang sempurna. Apabila terjadi multikolinier apalagi kolinier sempurna (koefisien korelasi antarvariabel bebas $=1$ ), maka koefisien regresi dari variabel bebas tidak dapat ditentukan dan standar errornya tidak terhingga.45Pengujian multikolinieritas dilakukan dengan melihat nilai VIF dan nilai Tolerance.Jika nilai VIF tidak lebih besar dari 10 dan nilai Tolerancetidak kurang dari 0,1 maka hal ini menunjukkan tidak terjadi problem multikolinieritas

3) Uji Autokorelasi

Uji autokorelasi bertujuan untuk menguji apakah terdapat korelasi atau hubungan antara kesalahan pada periode tertentu dengan kesalahan pada periode lainnya.Autokorelasi merupakan korelasi antara anggota observasi yang disusun menurut urutan waktu.Modelregresi yang baik adalah regresi yang bebas dari autokorelasi. Salah satu cara mendeteksi masalah autokorelasi adalah dengan melihat nilai Durbin-Watsson.

\section{Analisis Regresi Linier Berganda}

Metode analisis yang digunakan dalam penelitian ini, yaitu metode analisis regresi linear berganda.Metode tersebut digunakan untuk meramalkan pengaruh dari suatu variabel terikat (Profit) berdasarkan variabel bebas (Penerimaan kas dan Pengeluaran Kas).Berdasarkan spesifikasi model regresi maka model persamaan dalam penelitian ini adalah sebagai berikut

\begin{tabular}{ll}
\multicolumn{1}{l}{ Dimana } & $\mathrm{Y}=\mathrm{a}+\beta_{1} \mathrm{X} 1+\beta_{2} \mathrm{X} 2+\mathrm{e}$ \\
$\mathrm{Y}$ & $:$ Profit \\
$\mathrm{X} 1$ & $:$ Penerimaan Kas \\
$\mathrm{X} 2$ & $:$ Pengeluaran Kas \\
$\beta_{1} \beta_{2}$ & : Koefesien Regresi \\
$\mathrm{e}$ & : Eror Term
\end{tabular}

\section{E. Uji Hipotesis}

\section{1) Uji t Statistik (Uji Signifikan Parsial)}

Uji $t$ digunakan untuk menguji apakah suatu variabel bebas berpengaruh atau tidak terhadap variabel terikat.Pengujian secara parsial ini bertujuan untuk melihat seberapa jauh pengaruh satu variabel bebas secara individual dalam menerangkan variasi variabel terikat.

2) Uji f Statistik (Uji Signifikan Simultan)

Uji statistik f pada dasarnya menunjukkan apakah semua variabel bebas yang dimasukkan dalam model mempunyai pengaruh secara bersama-sama (serempak) terhadap variabel terikat.Uji $\mathrm{F}$ statistik dalam regresi berganda dapat digunakan untuk menguji signifikansi koefisien determinasi R2.Dengan demikian nilai $\mathrm{F}$ statistik dapat digunakan untuk mengevaluasi hipotesis bahwa apakah tidak ada 
variabel independen yang menjelaskan variasi Y disekitar nilai rata-ratanya dengan derajat kepercayaan k-1 dan n-k tertentu.

3) Koefisien Determinasi (R2)

Uji R2 menunjukkan adanya korelasi atau hubungan antara variabel independen dan variable dependennya. Uji R2 menjelaskan hubungan antara variabel dan factor lain yang mempengaruhi hubungan tersebut. Koefisien determinasi pada intinya mengukur seberapa jauh kemampuan model dalam menerangkan variasi variabel dependen. R2 merupakan besaran non negatif dan besarnya koefisien determinasi angka nol sampai angka satu $(0 \leq 1)$

Nilai R2 yang lebih kecil berarti kemampuan variabel-variabel independen dalam menjelaskan variasi variabel dependen amat terbatas. Nilai yang mendekati satu berarti variabel-variabel independen memberikan hamper semua informasi yang dibutuhkan untuk memprediksi variasi variabel dependen(Ghozali,2013:97) Untuk mencari besarnya pengaruh yang ditimbulkan oleh variabel independen terhadap variabel dependen digunakan koefisien determinan dengan rumus :

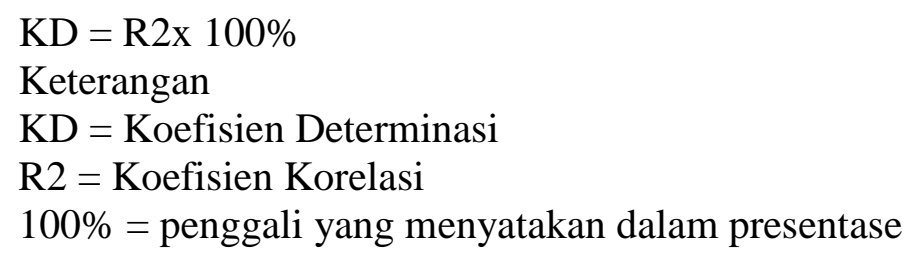

\section{HASIL DAN PEMBAHASAN}

\section{A. Uji t}

Uji t dilakukan untuk melihat besarnya pengaruh dan tingkat signifikan setiap variable independen terhadap variable dependen dilihat dari nilai signifikan :

1) Hipotesis $X 1$ Terhadap $Y$

Dari hasil penelitian pada variabel Penerimaan Kas (X1) diperoleh nilai t hitung sebesar 1,489 lebih kecil dari pada t Tabel sebesar 1,692 dan dengan tingkat sig 0.00 yang berarti nilai sig $<(\alpha) 0.05$ atau dengan taraf signifikansi kurang dari 0.05 maka $\mathrm{HO}$ diterima dan HA ditolak, dengan demikian hipotesis yang menyatakan penerimaan kas tidak berpengaruh signifikan terhadap profitabilitas pada PT. Restu Khairi Pratama terbukti tidak benar.

2) Hipotesis $X 2$ Terhadap $Y$

Dari hasil penelitian pada variabel Pengeluaran Kas (X2) diperoleh nilai t hitung sebesar -809 lebih kecil dari pada t Tabel sebesar 1,692 dan dengan tingkat sig 0.425 yang berarti nilai sig $>(\alpha) 0.05$ atau dengan taraf signifikansi lebih dari 0.05 maka $\mathrm{H} 0$ diterima, dengan demikian hipotesis yang menyatakan Pengeluaran kas berpengaruh signifikan terhadap profitabilitas pada PT. Restu Khairi Pratama terbukti salah. 


\section{B. Uji F}

Uji F yang dilakukan untuk melihat besarnya pengaruh dan tingkat signifikan antara variable independen secara simultan terhadap variable ini menggunakan SPSS 22 disajikan pada tabel 4.7 sebagai berikut :

Tabel 3.1 Hasil Uji F Menggunakan SPSS

\begin{tabular}{|l|c|c|c|c|c|}
\multicolumn{7}{c|}{ ANOVA $^{\mathrm{a}}$} \\
\hline Model & Sum of Squares & df & Mean Square & F & Sig. \\
\hline $\begin{array}{l}\text { 1 Regression } \\
\text { Residual }\end{array}$ & $2.521 \mathrm{E}+12$ & 2 & $1.261 \mathrm{E}+12$ & 1.127 & $.337^{\mathrm{b}}$ \\
\multicolumn{1}{|c|}{$3.356 \mathrm{E}+13$} & 30 & $1.119 \mathrm{E}+12$ & & \\
Total & $3.609 \mathrm{E}+13$ & 32 & & & \\
\hline
\end{tabular}

a. Dependent Variable: ProfiT

b. Predictors: (Constant), Pengeluaran Kas, Penerimaan Kas

Sumber : Data Olahan (2019)

Berdasarkan hasil perhitungan SPSS uji F, nilai $\mathrm{F}$ hitung yang diperoleh adalah sebesar 1.127 lebih kecil dari pada $\mathrm{F}$ Tabel sebesar 3.285 dan dengan tingkat sig 0.00 yang berarti nilai sig < (a) 0.05 maka dapat disimpulkan bahwa seluruh variabel independen secara simultan tidak memiliki pengaruh yang signifikan terhadap variabel dependen.

\section{Uji Deteminasi}

Hasil uji koefisien determinasi (R2) dengan menggunakan perhitungan SPSS 22 dari persamaan regresi disajikan pada tabel 4.10 dibawah ini :

Tabel 3.2 HasilKoefisienDeterminasi SPSS

Model Sumarry

\begin{tabular}{|l|l|r|r|r|}
\hline & \multicolumn{1}{|c|}{$\mathrm{R}$} & $\begin{array}{c}\mathrm{R} \\
\text { Square }\end{array}$ & $\begin{array}{c}\text { Adjusted } \mathrm{R} \\
\text { Square }\end{array}$ & \multicolumn{1}{c|}{ Std. Error of the Estimate } \\
\hline 1 & $.264^{\mathrm{a}}$ & .070 & .008 & 1057728.253 \\
\hline
\end{tabular}

Sumber : Data Olahan (2019)

Berdasarkan tabel tersebut dapat diketahui nilai koefisien determinasi (R2) sebesar 0.070 atau $0.70 \%$ Artinya variabel penerimaan kas dan pengeluaran kas berpengaruh terhadap variabel profitabilitas sebesar $0,70 \%$, sedangkan sisanya 90,30\% dijelaskan oleh variabel lain yang tidak dimasukkan dalam model regresi ini. 


\section{KESIMPULAN}

\section{A. Kesimpulan}

1. Penerimaan kas tidak berpengaruh terhadap profit pada PT. Restu Khairi Pratama. Hal ini dibuktikan dengan nilai t hitung sebesar 1.489 lebih kecil dari t tabel sebesar 1.692 dan signifikan sebesar $0.00<$ dari tingkat signifikansi yang disyaratkan yaitu 0.05 .

2. Pengeluaran kas tidak berpengaruh terhadap profit pada PT. Restu Khairi Pratama. Hal ini dibuktikan denga nilai t hitung sebesar -809 lebih kecil dari t tabel sebesar 1.692 dan signifikansi yang disyaratkan yaitu 0.05

3. Penerimaan kas dan pengeluaran kas secara simultan tidak berpengaruh terhadap profit pada PT. Restu Khairi Pratama. Hal ini dibuktikan dengan nilai F hitung sebesar 1.127 lebih kecil dari pada $\mathrm{F}$ tabel sebesar 3.285 dan signifikansi sebesar $0.00<$ dari tingkat signifikansi yang disyaratkan yaitu 0.05

\section{B. Saran}

1. Dengan hasil analisis yang telah dikemukakan maka diharapkan perusahaan lebih dapat meningkatkan efektivitas penerimaan kas dan menurunkan pengeluaran kas agar dapat lebih memaksimalkan profit sebuah perusahaan terutama di zaman global seperti sekarang ini.

2. Perusahaan yang menjalankan kebijaksanaan secara aktif, maka perusahaan harus mengeluarkan uang yang lebih besar untuk membiayai aktivitas pengeluaran kas 


\section{DAFTAR PUSTAKA}

\section{Buku-buku:}

Ansofino, dkk. 2016. BukuAjarEkonometrika. Yogyakarta: Deepublish.

Alma, Buchari, 2004. Manajemen Pemasaran dan Pemasaran Jasa. Edisi Revisi. Bandung : Alfabeta.

Bungin Burhan. 2013. Metodelogi Penelitian Sosial dan Ekonomi : Jakarta : Kencana In Damanhuri, S. Didin Dan Muhammad Findi, 2014. Masalah Dan Kebijakan Ekonomi Indonesia, Bogor : PT. Penerbit IPB Pres.

Fahmi, Irham. 2012, Analisis Kinerja Keuangan, Bandung: Alfabeta.

Hasan, Iqbal. 2004. Analisis Data Penelitian dengan Statistik, Jakarta : PT Bumi Aksara.

Juanda, Bambang dan Junaidi. 2012. Ekonometrika Deret Waktu Teori dan Aplikasi. Bogor: IPB Press.

Kasmir, 2010. Analisis Laporan Keuangan, Jakarta : PT. Raja Grafindo Persada.

Kusnadi, 2000, Akuntansi Keuangan Menengah (Intermediate, Prinsip, Prosedur, dan Metode, Universitas Barawijaya Malang.

Lukman Syamsudin, 2007, Manajemen Keuangan Perusahaan, Jakarta: PT. Raja Gragindo.

Mulyadi. 2012. Akuntansi Biaya, Edisi ke-5. Cetakan Kesebelas, Yogyakarta; STIM YKPN.

Munawir, 2014. Analisa Laporan Keuangan. Yogyakarta : Liberty.

Sugiyono, 2017. Metode Penelitian Kuantitatif, Kualitatif Dan R\&D, Bandung : Alfabeta..

Supriady, Edy. 2014. SPSS + AMOS. Jakarta: Penerbit IN MEDIA.

Supriyono, R.A. 2013. Akuntansi Biaya, Buku 2, Edisi 2, yogyakarta: BPFE

\section{Sitasi}

Fauzan Haqiqi, Darmawan, \& Kasirul Fadli. (2020). Analisis Pengaruh Likuiditas dan Pemberian Kredit Terhadap Tingkat Profitabilitas Pada Bank BPR Mega Mas Lestari tahun 2016-2018 Kabupaten Karimun. JURNAL CAFETARIA, 1(1), 7383. Retrieved from http://www.ejurnal.universitaskarimun.ac.id/index.php/akuntansi/article/view/5 3 